\title{
Playing with the line, channelling multiplicity: wind power planning in the Narbonnaise (Aude, France)
}

\author{
Alain Nadaï, Olivier Labussière \\ Centre International de Recherche sur l'Environnement et le Développement, Jardin \\ Tropical, 45 bis avenue de la Belle Gabrielle, 94736 Nogent-sur-Marine CEDEX, France; e- \\ mail: nadai@centre-cired.fr, Olivier.labussiere@centre-cired.fr
}

\section{Introduction}

Wind power is commonly considered one of the short-term solutions to greenhouse gas reduction. Its uneven development at the national level has triggered a growing literature interested in the institutional and social factors influencing it. These factors include institutional learning (eg, Breukers and Wolsink, 2007), social networks (eg, Agterbosch et al, 2009), project ownership (eg, Meyer, 2007; Warren and McFadyen, 2010), cobenefits for local communities (eg, Aitken, 2010), early public consultation (eg, Ellis et al, 2007; Toke et al, 2008), and fairness and trust-building (Aitken, 2010; Gross, 2007). The role of planning has also been discussed (Ellis et al, 2009; Nadaï and Van der Horst, 2010), notably in relation to landscape issues (eg, Nadaï, 2007).

In planning practices, mapping is a synthetic mode of acquiring and packing knowledge. It enables anticipatory action. However, because mapping does this, planning often becomes normative and tends to overlook the potentialities that are immanent in the territory or the landscape. It is fairly common for wind power planning approaches to endow cartographic forms with a prescriptive power and to deduce the future energy landscapes from the representations of existing landscape. ${ }^{(1)}$ The conventional analysis of graphic forms tends to reproduce this twist by focusing on the representational function of maps in planning processes.

In this paper ${ }^{(2)}$ we explore the way in which landscape is circulated in an innovative wind power planning process in southern France (Narbonnaise, Ande department, LanguedocRoussillon). By 'innovative', we mean that planners'decisions relate to the site/situation which they aim to transform rather than to preexisting norms or abstract territorial representations, as is so often the case in wind power planning processes. This planning process has a direct consequence: it succeeds in taking into account the existing local landscape and in engaging it in a transformative process.

This echoes to a certain extent the recent literature on park planning and conservation issues which has focused on how planning can account for and develop the way in which the local population practice and experience space. Analyses have shown how participation in (eg, Hoole and Berkes, 2010) or resistance to (eg, Bonta, 2005) planning processes can endow both planned space and local spaces with a new existence and pave the way for future changes, even if statutory or infrastructural achievements remain limited at the time of these processes.

Beyond such similarities, we focus on the relational properties of the graphic representations which underlie the Narbonnaise planning process. We make a contribution to the social analysis of representation, considered as the generic activity of bringing a reality into new types of existence. The argument developed is that the materiality of these representations (ie, cartographic lines, contours, figure/background 
relationships) is a relevant basis for adjusting new relations (density, covisibilities) which structure an emerging reality (wind power landscapes). Hence the title of the paper, "Playing with the line, channelling multiplicity", connects the materiality of graphic forms with the nonrepresentational-with the multiplicity of the emerging energy landscapes.

Our analysis is an attempt to overcome the opposition between representational and nonrepresentational strands in cultural geography. ${ }^{(3)}$ In the representational strand landscape and space are approached through their forms and the associated modes of representations; such a strand explores the impact of representations on social formations (Cosgrove and Daniels, 1988; Roger, 1997). The nonrepresentational goes the other way round: it involves a focus on social relations, social practices, and situated action as drivers of the emergence of new space and/or landscapes (Hetherington and Law, 2000; Lorimer, 2005; Nast and Pile, 1998; Rose and Thrift, 2000; Rose and Wylie, 2006). Our approach details both the forms of cartographic representations and the practices through which they are put to use in order to show how forms can set things in relation without fully determining the entities they assemble.

After presenting the material and the method (section 2), we analyse the way in which graphic representations have been developed and used throughout the Narbonnaise planning process (section 3). We rely on a Deleuzian framework, which enables us to structure our description round the relational properties of graphic representations (block diagrams, plans, text) and to analyse the way in which these representations contribute to the emergence of (new) wind power landscapes. We then propose a theory of these relational properties and the quality of the planning process, drawing on STS theory (section4).

\section{Material and method}

In this paper we analyse the way in which graphic forms endow cartographic representations with relational properties that make planning constantly refer to the site/situation it aims at transforming (ie, abductive instead of normative) $)^{(4)}$. In order to do so we rely on a Deleuzian framework (Labussière, 2011) ${ }^{(5)}$. From Deleuze we borrow three concepts that enable us to structure our description around the relational properties of graphic representations: 'map'/'tracing' and 'sign'.

The opposition between 'map' and 'tracing' points to the difference between a device that is continually related to reality (map) and a closed representation (tracing), which selects and isolates what it aims at reproducing. The map is characterised by social practices which allow it to maintain a relation to its object. Deleuze and Guattari (1980) define the concept of 'map' as a device that is open to the real. They oppose it to 'tracing'(6), which starts by "selecting and isolating what it aims at reproducing", "only ... to reproduce itself" in the end (page 21). A tracing thus pretends to copy the real but remains fundamentally self-referential. The map, on the contrary, is constructed through multiple connections to the real, without necessarily claiming closure or signification. In other words the map produces; the tracing reproduces.

\section{1 'Map/tracing'}

The concept of 'map' has aroused the interest of some geographers, mainly Anglophone. It is most often invoked to support postmodern criticism in geography (Dewsbury, 2000; Doel, 1993; Edney, 1996; Thrift, 2000) but it is rarely used as a conceptual basis for cartographic analysis, with only a few exceptions (Crouch and Matless, 1996). ${ }^{(7)}$ Distinguishing between 'tracing' and 'map' solely by means of an opposition, however, seems reductive. Deleuze's quest to supersede form is always balanced by cautious 
warnings aimed at preserving some of the qualities of form (Buydens, 2005; Deleuze and Guattari, 1980, page 199). The issue, therefore, as we understand it, is not to choose between the formal and the a-formal. It is, rather, to open up a perspective in which the articulation between the two becomes possible, so that we can account for the primacy of an a-formal real in the emergence of novelty as well as for the role of forms in experimenting with new becomings.

We share with the materialist interpretation of Deleuze's geophilosophy an interest in bringing Deleuzian philosophy into the field (Bonta, 2005; 2009) and into sociological analysis (De Landa, 2006; Van Wezemael, 2008). Mapping, in our view, is related to the virtual through the play of unprecedented and unqualified relations that it first sets, paving the way for the emergence of unforeseen compatibilities and realms. Such a relational potential can be sustained by and circulated through cartographic forms and practice. The properties of forms and practices that contribute to sustaining this relational potential can be followed in actual planning processes - that, at least, is the purpose of this paper. Asserting that the circulation of this potential can be traced does not imply not that the virtual is translated into actual representation in these processes ${ }^{(8)}$ but, rather, that multiplicity finds a way through cartographic practice and forms. In other words the relational properties of the map allow for a circulation between map and tracing. It is possible to enter the map, to construct it or to freeze it, by using tracing.

\section{2 'Sign'}

The concept of 'sign' is used to specify the relational properties of cartographic practice. Deleuze defines the sign by its power to endow agents with the capacity to relate in new situations (in 'heterogeneity') rather than merely to replicate the sign as a code:

" the movement of the swimmer does not resemble that of the wave; in particular, the movements of the swimming instructor that we reproduce on the sand bear no relation to the movements of the wave, which we learn to deal with only by grasping the former in practice as signs .... Our only teachers are those who tell us 'do as I do', and are able to emit signs that are to be developed through heterogeneity rather than propose gestures for us to reproduce" (2005 [1968], page 35). ${ }^{(9)}$

In the same way graphic codes and forms are only one element in planning; more important is the ability they convey, through the practice of planning, to relate to the situation that planning aims at transforming.

2.3 Planning as a map, scale as a sign, and the relational potential of cartographic forms These three concepts allow us to trace and qualify the relational properties of cartographic representations. The Narbonnaise planning process is approached as a map. It is conceived of as a process through which social practices (networking, public meetings, consultation with stakeholders, use of graphic codes, etc) and forms (written and graphic supports) jointly engage planning in a relation with its object (landscape). In exploring how this is achieved points to the key step of producing a 'scale', (10) which sets a circulating reference to the site/situation and endows graphic representations with definite relational properties. In other words, we explore the capacity of cartographic forms to circulate a sign (a 'wind power scale' in our case), and to engage a situation (the landscape) in a relational existence and a new becoming ('wind power landscape').

Our analysis relies on graphic and written documents, and on fieldwork and face-toface interviews (thirty-three interviews) conducted in three campaigns over the space of two years (2006-07). The interviews were undertaken with the various parties engaged in the planning process, including: the local state administration (ministerial field services); 
territorial organisations such as the PNRN, whose board is made up mostly of local mayors; local mayors; pro-'wind' or anti-'wind' NGOs; and two private landscape companies, which were commissioned to draw up the PNRN Wind Power Charter.

As the participation of private companies in the planning process was one innovative dimension of the PNRN process, we conducted several (separate) interviews with both landscape companies. These interviews included a close examination of each of the successive maps that had been produced during the planning process (the maps were spread over the meeting table). This enabled us to reconstruct the planning process step by step and to recall some steps in the development of the cartographic representations (eg, in-house or out of house work, comings and goings in the field) that were informal but essential to the understanding of (displacements in) the planning process. This work has been complemented by the analysis of one landscape company's archives (calendar, questionnaire sent to the mayors, field notes) and by fieldwork and interviews with other actors-such as, wind power developers, NGOs (environmental or bird protection organisations) $)^{(11)}$ local mayors and representatives of the PNRN-so as to bring the work and voice of the landscape company into perspective with the other voices engaged in the process.

\section{From landscape to wind power landscape: the Narbonnaise experience}

The Parc Naturel Régional de la Narbonnaise (Regional Natural Park of the Narbonnaise, PNRN) covers the eastern part of the Aude department (Languedoc-Roussillon, southwestern France), which stretches along the Mediterranean coast just north of the Pyrenean mountains and the French-Spanish border. Since the adoption of fixed tariffs in France in 2000, the Aude and especially the windy Narbonnaise have been pioneer sectors in the development of French wind power. With the exception of seaside municipalities drawing an important income from tourism, most rural municipalities in the Narbonnaise are interested in hosting wind farms. By the end of 2007, ten wind farms (110.2 megawatt, ninety-two windmills) had been installed on the territory of the PNRN and various planning documents (at the regional, departmental, and PNRN levels) had already attempted to regulate wind power development (PNRN, 2003; Préfecture de l'Aude, 2005; Région Languedoc-Roussillon, 2003).

The PNRN Wind Power Charter was adopted in 2003. In 2006 it became legally binding through its inclusion in the Narbonnaise master plan. This charter sets the boundaries for favourable and nonfavourable zones for wind power developments-so-called 'wind power envelopes'-as well as outlining specific landscape recommendations for each envelope ('repowering' [the dismantling of existing wind farms/installation of new, more powerful, wind turbines], 'densification', 'dismantling'). This was also the only local planning process to bring together mayors, wind power developers, NGOs, and ministerial field services in a consultation: "it is true that [the charter] was not devised by a state department ... it was devised by mayors, NGOs ... we can say that the approach was based on rather broad participation".(12)

Our analysis follows the development of the charter from the time it came into effect in 2002 until the autumn of 2007, by which time it was being used by the local administration to grant or refuse authorisation to wind power projects.

\subsection{Turning a landscape into forms: producing a (wind power) scale}

\subsubsection{Seeing the scale}

During 2002 the U-agency ${ }^{(13)}$ was commissioned to design the PNRN Wind Power Charter.

Even though it was familiar with the Narbonnaise and the Corbières landscapes, the 
agency perceived the need to undertake an intensive fieldwork session in order to acquire a sense of the presence of (future) wind turbines in the landscape and to find ways of conveying it. The director described this fieldwork session as an intense experience of "[wandering] all- around" and multiplying perspectives, which led to the emergence of a 'scale':

"What was difficult was to produce a new scale. I'm an architect by training. In my training, someone was always telling me: 'get used to always having a scale in your eye ... it can be the ruler, you know what 12 inches amounts to ... then, you have this in mind when you draw something'. But here [with wind power], it's very different, it isn't one metre fifty! Then you wonder where is the right scale here? It's crazy. Where do I see that scale?

... If I figure it in relation with this hill, what does that give me? If I figure it in relation with this village, what does that give me? Can I picture it?" (14)

The scale at work emerges when one experiences the confrontation of a (hypothetical) wind farm and the different scales (the topography, the village) of the landscape. It is a mode of relating that is specific to wind power. Experiencing it through the landscape, incorporating it (the 'scale in the eye'), enables the landscape architect to reproduce it and translate the presence of the turbines into representation. Like the movement of the swimmer, the scale circulates and enables the architect to produce a multiple representational device (consisting of a map, block diagrams, and text) that translates his or her trans-scalar experience of the landscape.

\subsubsection{Picturing the scale}

Early on, the director felt the need to represent the landscape units that she perceived during her fieldwork. The act of drawing is part of the process of acquiring the relevant scale. The resulting graphic device is composed of three block diagrams (large-scale diagrams of the site) (see figure 1) and a map of the landscape units (small-scale map of the Narbonnaise) (figure 2). These elements are meant to 'function together'.

The block diagrams have been drawn in situ. They are very realistic: they picture the topography, the villages, the woods, and the farming activity (eg, figure 1). Each block diagram illustrates a situation that is judged to be both 'emblematic' of the landscape unit under consideration and relevant to understanding the relation between wind power and landscape. Even if the elements represented clearly refer to a territorialised unit-localities, villages, and access ways are named-the scale of the drawing is not quantified. This prevents a metric reading and endows the blocks with a metonymical dimension. The general perception of the shapes and of the organisation of the sector prevails over a territorial vision: "The important thing [in the Corbières block] was ... the way the villages were sited .... We're in things that are a bit of a mess". ${ }^{(15)}$ The virtue of these blocks is that they render the big landscape (the small scale) through the figuration of a site (the large scale), the general through the particular. By doing this, the agency aims at bringing together two different states of the landscape. Wind power calls for "simultaneously getting hold of two scales". (16) The large and the small landscape are engaged in a relation of codefinition because wind turbines raise far-reaching covisibility as well as proximity issues. "Wind power is a colonial thing!" (17) and the problem is "how large an area [to] cover in considering the landscape?"(18) because of 'covisibilities'.

The dialogue between scales is prolonged through the accompanying map (figure 2). The map orders the perception of the relations between wind power and the landscape (visibility, presence) on another scale (small, the Narbonnaise) by setting down "very quickly three large elements of the landscape: the broad Aude valley, the seashore and 
the Corbières". Yet it remains inclusive and so open. It does not fix relations and landscape units into a territorial delineation. It is "broadly catching at the margins". ${ }^{(19)}$

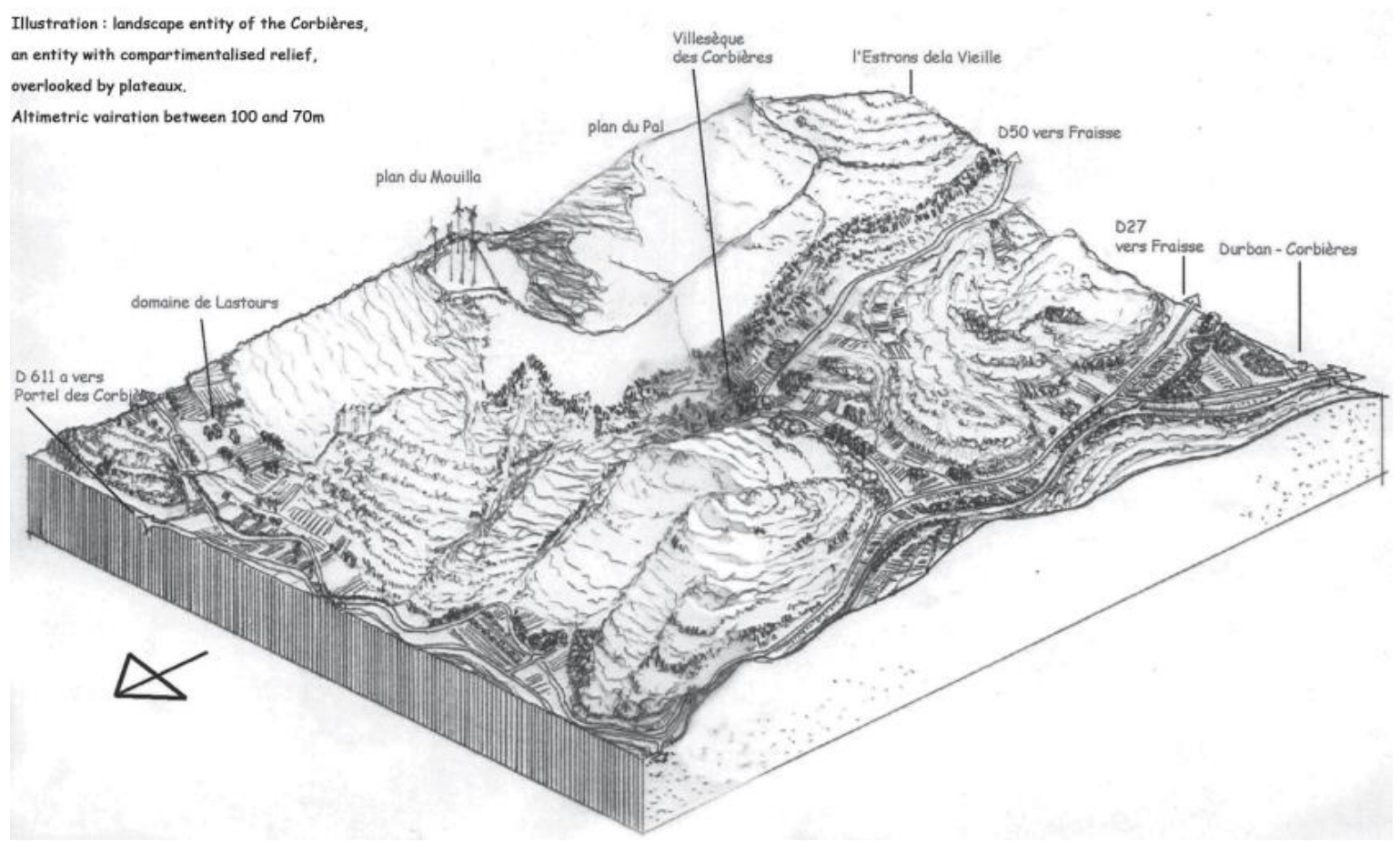

Figure 1. Block diagram for the compartmentalised Corbières massif (source: PNRN, 2003; designed by Agence Urbane on behalf of the Parc Naturel Regional de la Narbonnaise).

The way in which this is achieved is by playing with graphic forms and lines (see figure 2). The map background is designed (blurred, two-colour treatment) to give a feeling for topographic variations, entities (the massif and its slopes, the plain, the shore), and relations (compartmentalised/open, up/down) without indexing them to an altimetry. Alarge blue arrow indicates the structuring force of the seashore, both as an entity and as a mode of relating to the other elements of the landscape. The line is flowing, with upstrokes and downstrokes. It is loose, suggestive, intentionally rough, like a sketch, as echoed by the handwritten-like inscriptions. Continuities, differences, and structuring relations are prioritised over territorial divisions and assignments.

Intuitive at first glance, this boutiquage-a term used by the director to qualify this type of in-house graphic design - "corresponds to a certain step in mastering the map and the discourse". It serves a double purpose: "it is there to display the intentions on the large scale" but also to question the delineation of naturalised entities: "to raise questions such as - the Corbières massif, where does it really begin?", (20) In other words the graphic line suggests an order (to be) made up of three entities, without assigning it to absolute coordinates, whether natural, spatial, or territorial.

Graphic inventiveness thus allows the agency to link the plan to the landscape situation without reducing the latter to a zonal logic. In contrast to the other wind power planning schemes (the departmental planning or the regional scheme) this cartography partakes of practice rather than of representation. Like the Deleuzian sign, the play of relations referred to by the map is a resource for reinventing landscape relations: "it is different conceiving an intervention in the compartmentalised massif, an intervention in the plain or an intervention on the shore. One might have three different ways of revealing the landscape". It is aimed at making "issues of landscape structure ... intelligible to everyone"(21) and particularly to the PNRN steering committee, made up of local 


\section{Three large landscape units:}

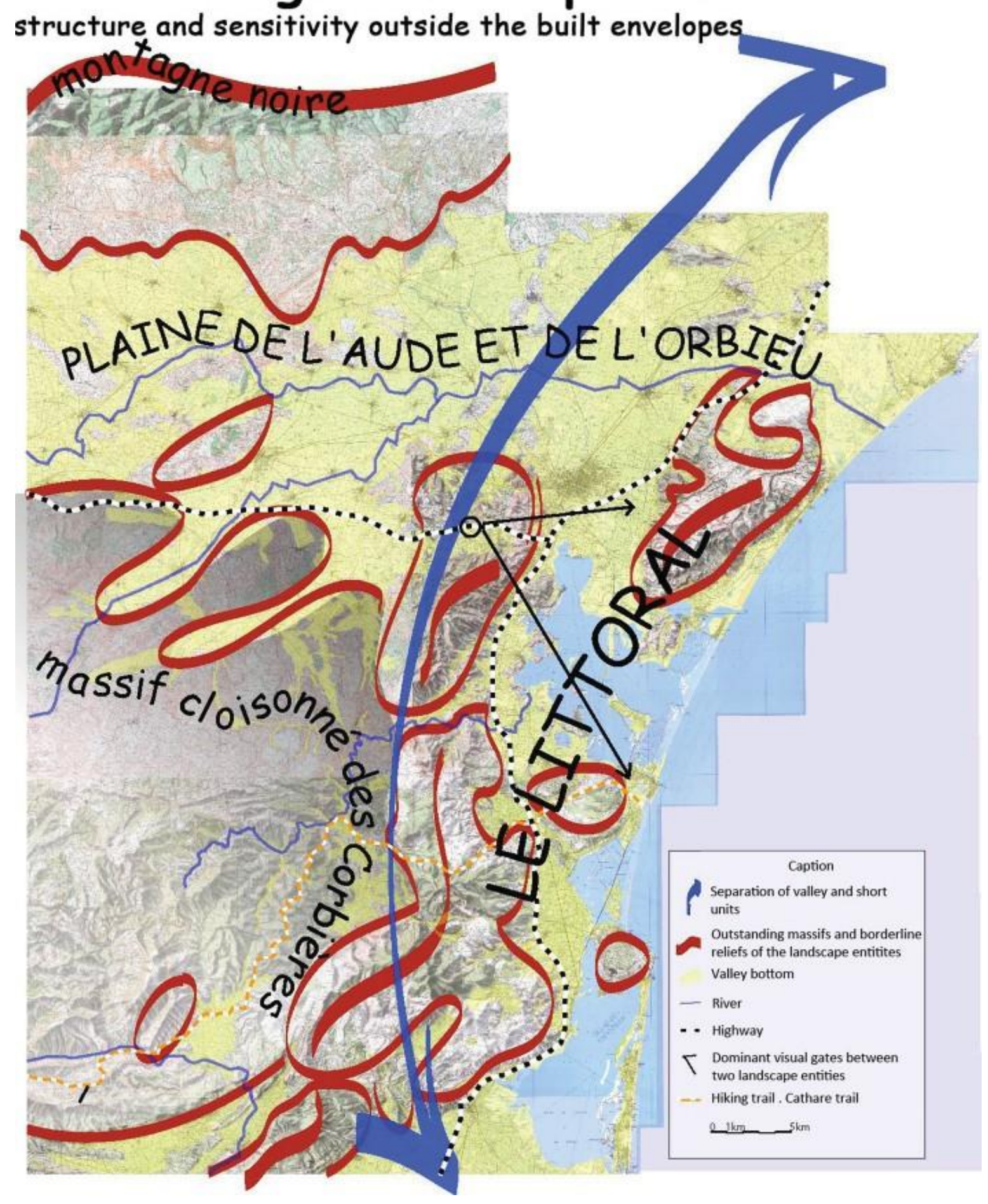

Figure 2. [In colour online.] The three large landscape units: the compartmentalised Corbières massif, the shore, and the Aude and Orbieu plain (source: PNRN, 2003; designed by Agence Urbane on behalf of the Parc Naturel Regional de la Narbonnaise).

\subsubsection{Relating through the scale}

The map (the large landscape) and the block diagrams (the small landscape, the site) 'work together' to make these issues more intelligible. Through its loose delineation, the map suggests an open order that the blocks come to illustrate by figuring situated viewpoints 
in each landscape entity. Because they characterise the map order according to situational principles, the blocks exempt the line of the map from spatial/territorial delimitation. They relieve it of part of its representational load. Conversely, the order of the map (eg, the similarity of situations within each landscape entity) endows the blocks with a meaning that exceeds the sites from which they derive. Metric proportions or territorial/spatial delineation ends up being of secondary importance. The realism of the blocks mainly serves the description of landscape relations and makes it easier for mayors and local actors (members of the PNRN steering committee) to relate to the situations pictured.

This encompassing iconographic strategy enables the agency to progressively share the view that wind power pulls a familiar landscape into a new existence-"here wind power comes to say that the landscape exists, the landscape which you see every day but which you don't see anymore"(22) - and that territorial assignation (where will wind power projects be developed and which communities will be authorised to develop projects on their territory?) is less important than the relational interplay between landscape and wind power. The (wind power) scale under construction starts to circulate and endow the parties with an ability to think about this relational interplay.

\subsection{Turning forms into politics: sharing the scale}

\subsubsection{Reopening territorial data}

In order to guarantee the legality of the future wind power projects, the charter had to take account of the regulatory constraints (urban plans, heritage protection, environmental protection, etc). Early on, two conflicting visions confronted one another within the PNRN steering committee. On the one hand, the Languedoc-Roussillon environmental administration (DIREN) ${ }^{(23)}$ called for constraint planning-that is, for planning a scheme that superimposed zonings on a synoptic map so as to indicate regulatory constraints and delineate zones for the development of wind power projects. ${ }^{(24)}$ On the other hand, the president of the PNRN steering committee joined the agencies $^{(25)}$ in opposing "a scenario of equipment or non- equipment" (PNRN prefiguration group, 2002, page 4) and defending concerted decision making among elected representatives:

"The impact of wind power [in the Narbonnaise] was such that, at a given point, the

Prefect had put a check on it ... . Local mayors joined us out of their own interest ... I

insisted that, if we did not agree on this [the charter], we would get no wind power.

Then we had to define rules, decide on the number of turbines, etc ...".(26)

The agencies, backed by the president, won the battle and proceeded in three phases. First, an inventory of state-declared delimited areas and regulatory constraints (June-July 2002) led to the creation of 'data maps' (eg, figure 3) and to the conclusion that "strict bans [on wind power developments] are very limited in the PNRN territory". (27) Second, a questionnaire survey asking for the prioritisation of various regulatory criteria was addressed to the members of the PNRN steering committee (ie, about eighty persons including elected representatives, associations, territorial institutions, administrations) (September 2002). The questionnaire consisted of a grid whereby members could prioritise various regulatory criteria (weak, middle, strong) according to their own judgment and argue for their choices. Two maps were attached to the questionnaire: the first displayed the regulatory zonings submitted for consultation ("cultural and environmental sensitivities listed by the administration or other local actors"); the second was empty and intended for additional annotations. The questionnaire led to modest results from 
which the agency was unable to derive an exclusion zone for wind power (about 15 answers showed some concern for a 'zone of ecological, zoological, and botanical interest). These results suggested that the planning of wind power was open to negotiation and led to a postponement of the actual treatment of regulatory constraints until the next step, two day-long consultation workshops (17 and 18 October 2002).

\section{RECOGNIZED NATURAL INTERESTS}

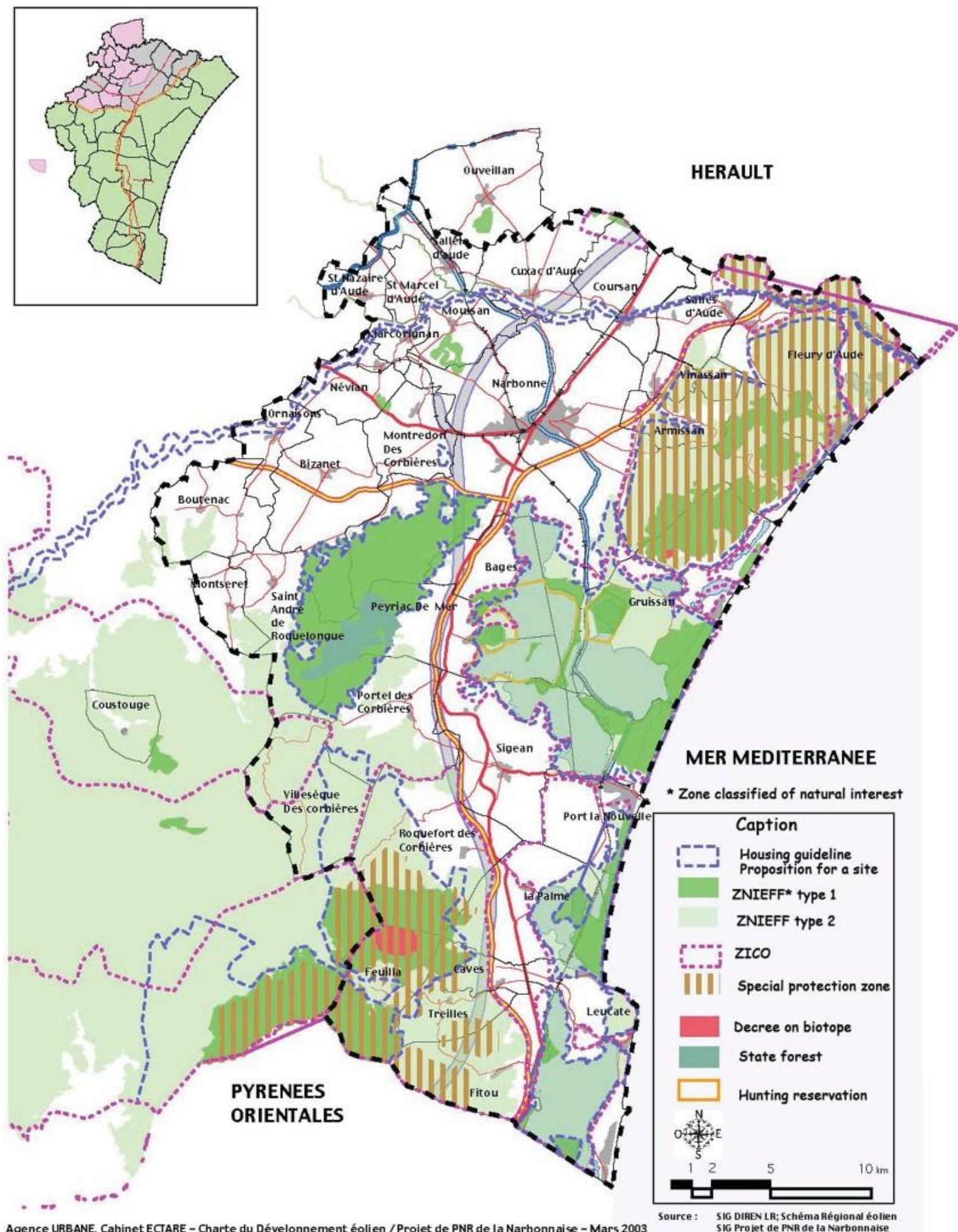

Figure 3. [In colour online.] Recognised natural interests (source: PNRN, 2003; designed by Agence Urbane and Agence Ectare on behalf of the Parc Naturel Regional de la Narbonnaise).

\subsubsection{Reopening territorial forms}


As a landscape designer, the director of the U-agency was faced with a challenge: "Protection perimeter [is] territory; it isn't landscape! One is inside or outside, but that doesn't say anything about the quality of the place! ... . To start with a limit is a territorial vision." The scale was envisioned as a perspective enabling the designer to bridge the gap between 'territory' and 'landscape' conceived as two radically different, if not opposite, orders: "What can I do to reach the missing scale? How to depart from 'territory' and reach 'landscape'?" (emphasis in original). ${ }^{(28)}$ 'Territory' is data and a way of indexing; 'landscape' is a quality and a way of circulating. The challenge for the consultation was to find a way to process territorial data in a device that could indicate wind power zones without indexing the definition of these zones to territorial limits.

Inventory maps were the graphic form that served this purpose (eg, figure 3). They displayed regulatory zonings, which had been designed on the scale of the parcel, independently of the territorial grid to which these zonings referred. The map background pictured only the main roads and municipal limits - "a reference for the mayors"(29) —in order to make reading the maps easier during the consultation workshops. Transcribing a territorial form in this way without its matching spatial background loosens the ties between the form and its territorial interpretation. The map still treats the territory as data and an index (the contour and the classification of the zonings are both referred to a territorial order) but its constitutive scalar mismatch makes it nonnormative and calls for resolution through renewed circulation.

The workshops were held over the space of two days. The first day was organised round themes (heritage and landscape, environment, human activities), and the second around geographical regions (the Corbières massif, the Aude plain, the shore). Each workshop was attended by an average of about ten people, including local elected representatives $(40 \%)$, wind power developers (30\%), NGOs (20\%), and urbanist and landscape companies (6\%). Ministerial field services (3\%) showed very little presence; only DIREN and the Direction Départmentale de l'Equipement (local administration in charge of roads and infrastructures) participated in these meetings. Each workshop was aimed at devising a 'draft of an ideal map', including exclusion zones as well as wind power zones. As is clearly stated in a preparatory document, the work was explicitly aimed at refraining from planning by constraints ('negative planning'): "The purpose is not to direct wind power developments to unqualified areas, nor to fill the gaps left by the patrimonial areas or zones under environmental protection, but rather to compose a landscape that takes the turbines into account." (30)

\subsubsection{Floating open forms, relating landscape experience}

During the workshops, the inventory maps were pinned to the wall and used as input in the collective exercise: "Each time, we showed them the territory from the angle of the theme under discussion [for instance, environment] ... here is your territory, here are the strong zonings ... [proposed as] a working basis. But the ranking of these zonings was done during the workshop ... everybody was contributing." (31) Collective contribution was facilitated by calls round the table and by a 'floating' use of the inventory maps. These were manipulated as removable calques: "We superimposed them. We made transparencies in order to obtain layers and, as the discussion unfolded, drew on the transparencies ... and then we reached a synthesis". ${ }^{(32)}$ As inventory maps were added and removed at will, visual effects of clustering contributed to the demarcation of new spaces that the participants could contextualise, either individually or collectively, based on their "very close knowledge of the places". ${ }^{(33)}$ The process shifted from a quantitative multiplicity (the addition of regulatory constraints) to a qualitative multiplicity, based on 
shared values and revealing landscape entities as they were experienced by the participants. Individual references (such as a brook) were indicated as important but so were collective ones, such as the massif of 'La Clape': "Very early on,

... it was inconceivable to them to imagine La Clape with wind turbines at its top". ${ }^{(34)}$ The process thus enabled "people living in the park" to identify "what is endowed with a shared value". ${ }^{(35)}$ In the meantime two different scales and orders were interwoven together: the small scale (Narbonnaise)/territorial representations (calques) and the large scale (locality, site, neighbourhood)/landscape.

The maps that emerged from these workshops (see figure 4) display exclusion sectors as well as sectors for 'possible wind power development'. One sector, Portel-lesCorbières, where a wind farm project was already under design, was subjected to intense negotiation. DIREN was opposed to a favourable envelope because of potential covisibilities with a protected abbey (Fontfroide). Because the mayor had dedicated resources and time to the wind project, a specific envelope-subject to stringent and long-term requirements for wind power developments-was created (yellow and green hatching in figure 4). Yet, as ECCLA (a local environmental NGO participating in the workshop) commented, the resulting map materialised a step in a process of emergence rather than a final decision: "there were compromises. Certain zones are not necessarily areas in which we would like to have turbines. The PNR [Parc Naturel Régional] still has to give a favourable decision for us to consider having turbines there."(36)

A draft of a synthesis map was produced on the basis of the workshop maps. It was discussed in a final workshop (see figure 5). The graphic design of the workshop maps reflected the method as much as the final content. It was reminiscent of manual production. The maps were "blurred, but not too much" and partook of "a range of compromise, of discussion, of what was experienced and shared at a given moment." They were "maps of intentions, intentions that would not betray [the compromise that was reached during the workshop]". (37) Landscape recommendations, meant to convey the content of the discussions, were assigned to each envelope. These recommendations were attentive to local configurations (eg, the need to keep the turbines away from the edge of the plateau, from the existing wind power site of Lastours, etc). In so doing they related the small scale on the map to the large scale of the sites and maintained the circulation between scales that underlay the overall approach.

In the end the process was neither a scaling up nor a scaling down. It worked its way between two scales and two states of the landscape, while further specifying rules for their cohabitation. Through the consultation workshops, these rules became shared by a wider community. They were also applied in a more specific way to restricted areas: the wind power envelopes. Yet they were not fixed once and for all, as tensions occurring between DIREN and other members of the PNRN steering committee about several envelopes during this step of the process attested. The 'intentions' contained in the workshop maps still had to be sharpened in order to provide a genuine planning document and framework. 


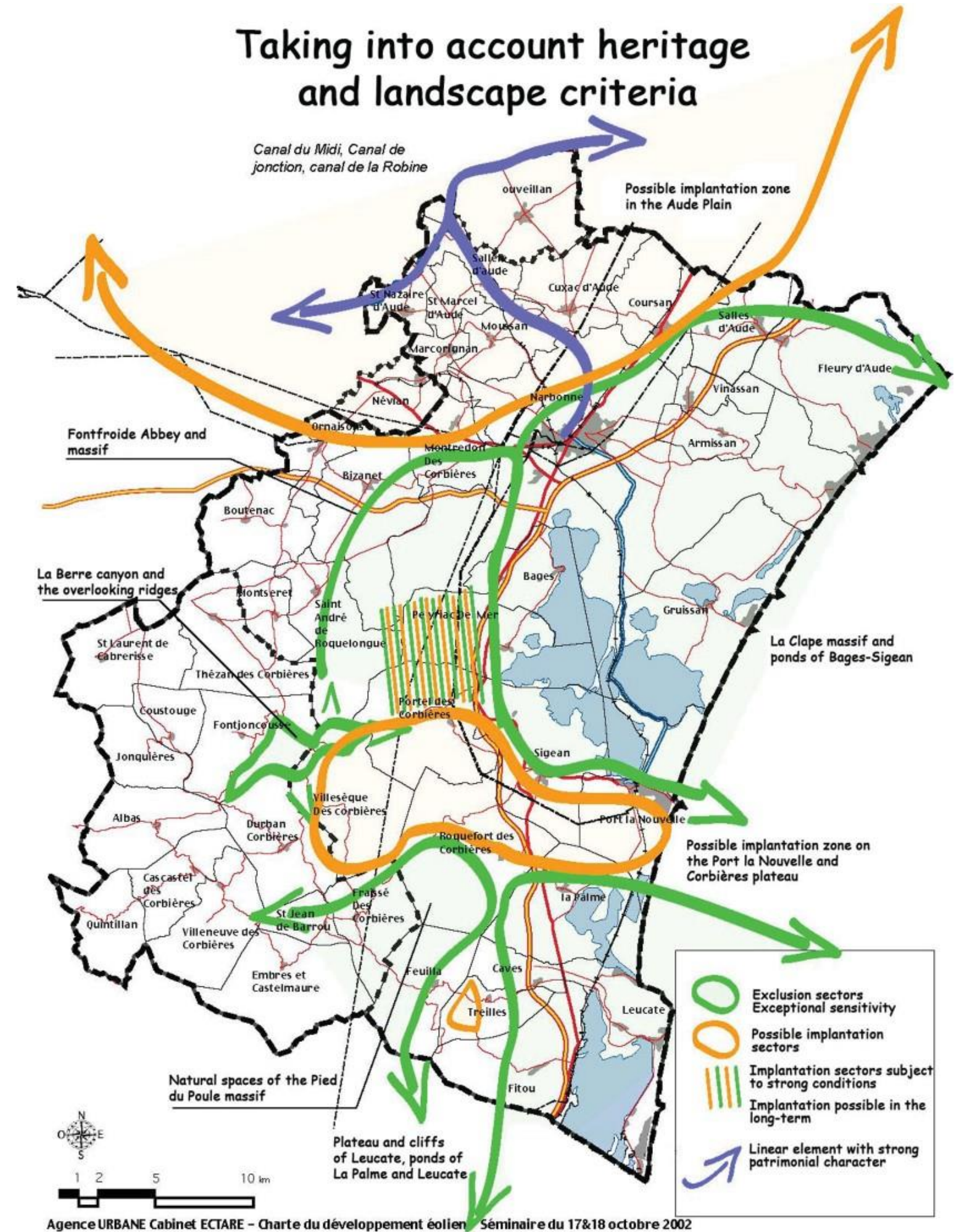

Figure 4. [In colour online.] Theme: heritage and landscape (source: PNRN, 2003; designed by Agence Urbane and Agence Ectare on behalf of the Parc Naturel Regional de la Narbonnaise).

\subsection{Impoverishing forms: circulating the scale}

In order to refine the envelopes the agency had recourse to a detailed topographic background (see figure 6). In-house work enabled the agency to reduce the size of the envelopes significantly by merely contouring them. Some envelopes were wedged into the perimeter of their respective plateau (eg, Port-la-Nouvelle/Sigean in the southeast, Villesèque-des-Corbières in the southwest). 


\section{Synopsis of thematic workshops : \\ Possible implantation zones}

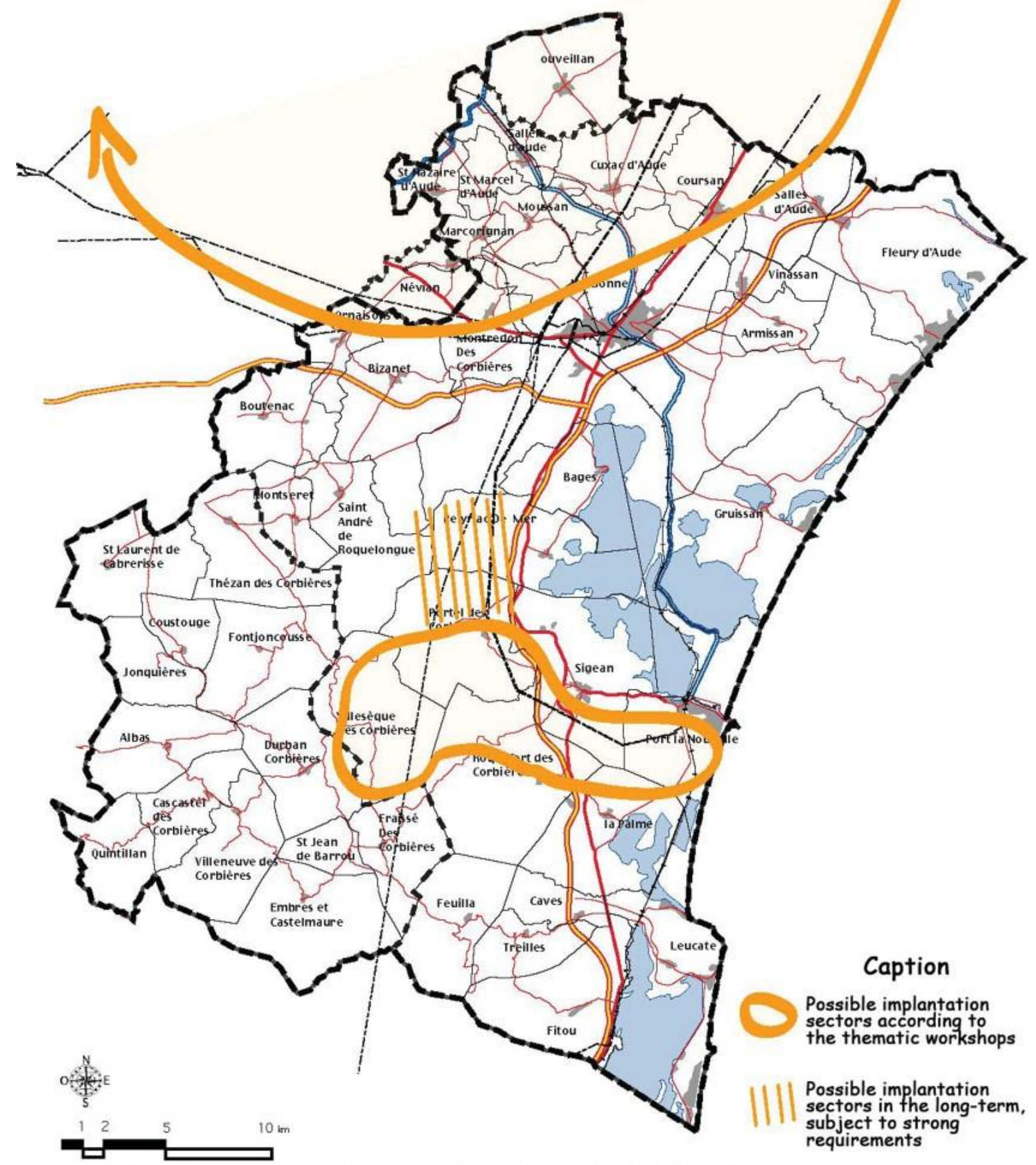

Agence URBANE Cabinet ECTARE - Charte du développement éolien - Séminaire du $17 \& 18$ octobre 2002

Figure 5. [In colour online.] Synopsis of favourable zones for wind power as defined in the workshop (source: Agence Urbane archives).

\subsubsection{Impoverishing the form}

Amazingly, the final map figuring the envelopes (see figure 7) in the charter document (PNRN, 2003) radically differed from the agency's internal document (figure 6). The topographic background vanished. It was replaced by a minimalist graphic background similar to the ones used for inventory maps during the consultation workshops. As in the inventory maps, here, too, the background endowed the envelopes with a floating character. The 
envelopes themselves appeared in a new graphic form: they were pictured as thickly drawn, almost abstract ellipses. If their sizes reflected their recent topographic wedging, their schematism prevented a territorial reading.

\section{Favourable envelopes for wind farm developments}

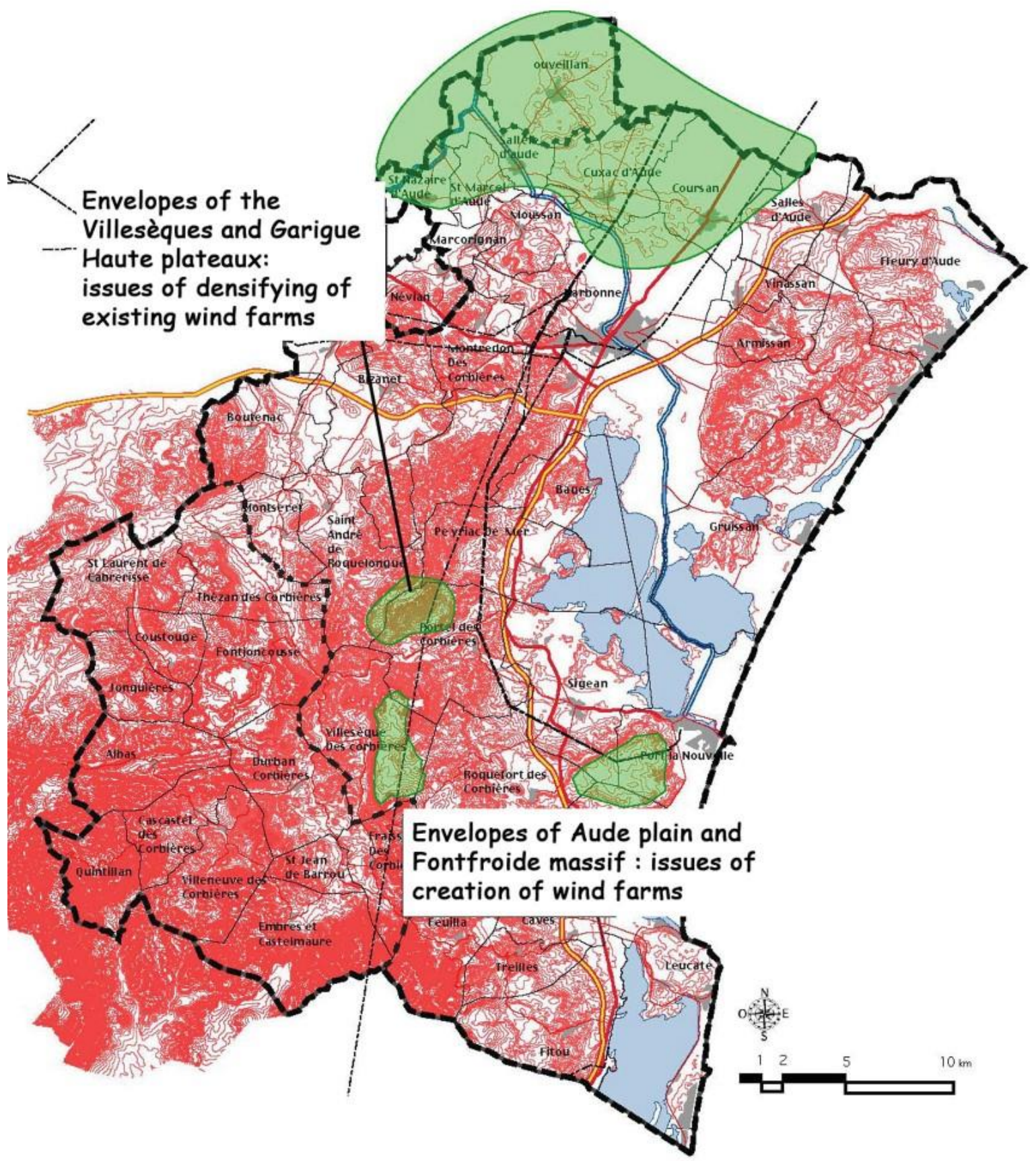

Agence URBANE - Cabinet ECTARE - Charte du dèveloppement éolien Sèminaire du 17 \& 18 octobre 2002

Figure 6. [In colour online.] Internal document of the U-agency: possible sites for wind farm developments (source: Agence Urbane archives).

3.3.1.1 Why did the agency erase the results of scaling up? 


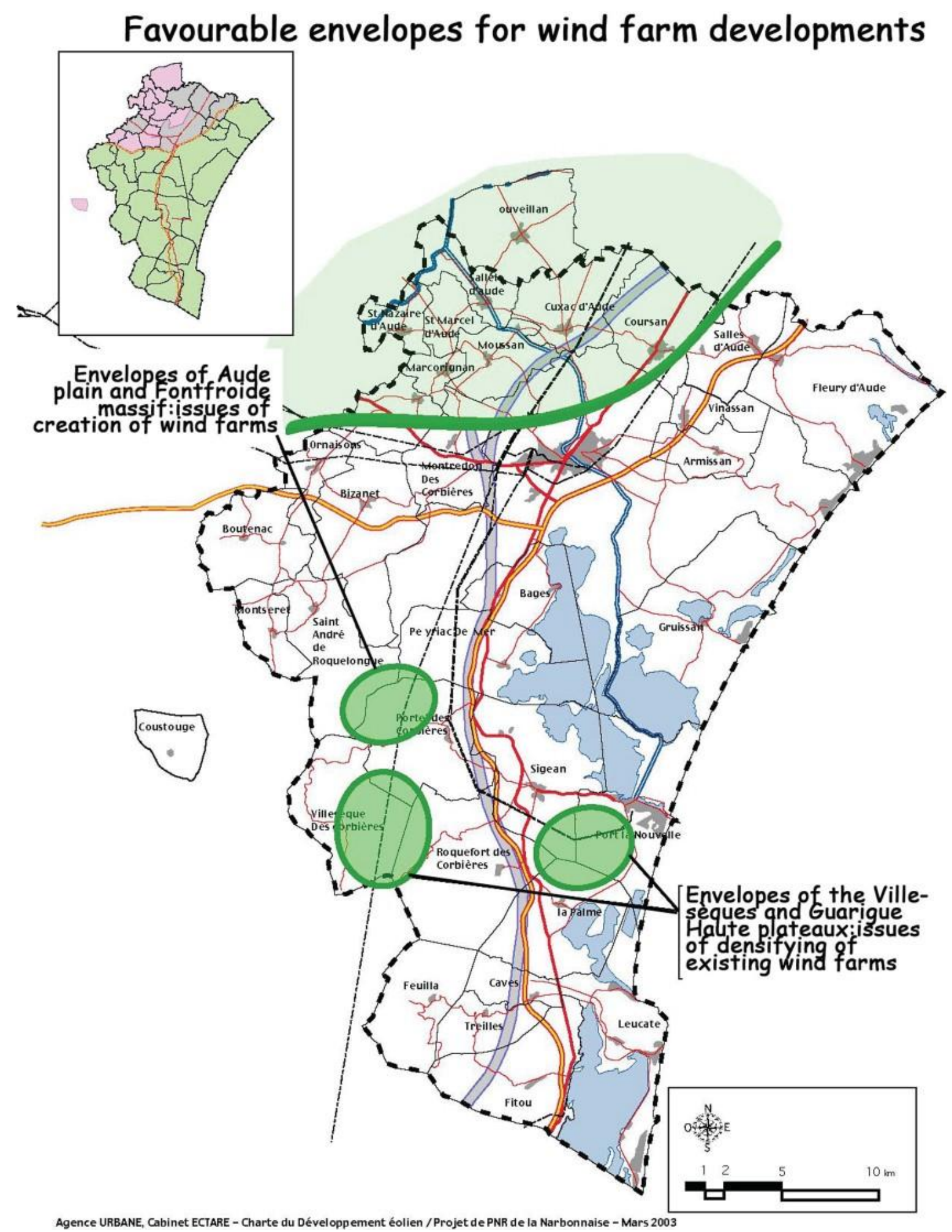

Figure 7. [In colour online.] Favourable envelopes for wind farm development; map included in the final report (source: PNRN, 2003; designed by Agence Urbane and Agence Ectare, on behalf of the Parc Naturel Regional de la Narbonnaise).

As part of the charter synthesis report, ${ }^{(38)}$ the final map was meant to be used for orienting wind power development in the PNRN. It was intended for a large public and given a political dimension. The PNRN steering committee asked for a more schematic rendering before the final distribution in order to protect itself against any "negotiations on the line (sic)"(39) - that is, against attempts at gaining legitimacy for a wind power project solely on the basis of territorial logic ('inside/outside' the envelope) and in the 
absence of reflection upon how the projects would relate to the situation addressed by each envelope. Hence the new schematic rendering is aimed at facilitating consensus, particularly among mayors tempted to interpret the envelopes (too) accurately through the prism of municipallimits.

As graphic forms, the envelopes had been impoverished and become enigmatic. They roughly indicated zones for wind power development without inscribing these zones into any definite place or topography. Their (new) graphic indigence made the envelopes resistant to contour reduction and endowed the principles included in the landscape recommendations with increased stability and long-term validity. It put these principles into a sort of suspended animation, holding them ready for in situ reactivation by future wind power developers. In other words the envelopes did not convey a programme of development to be carried out but became hieroglyphs to be deciphered in situ.

The final map (see figure 7) came with landscape recommendations, which were illustrated by block diagrams and site maps for each envelope (see figure 8). As in the first period of the process, the allocation of the referencing load among various graphic modes enabled planners to avoid spatial delineation and zoning logic, and to propose principles for how to relate to the different situations. The map points to situations for siting without demarcating the corresponding sites. The blocks, once endowed with such an open frame, can invest the corresponding situations and visualise siting principles.

\section{Organisation on a continuous line}

\section{- Organisation on a line parallel to the shore, regularly spaced implantation, \\ - homogeneity of machine design (size, size of wings, cabin, colour)}
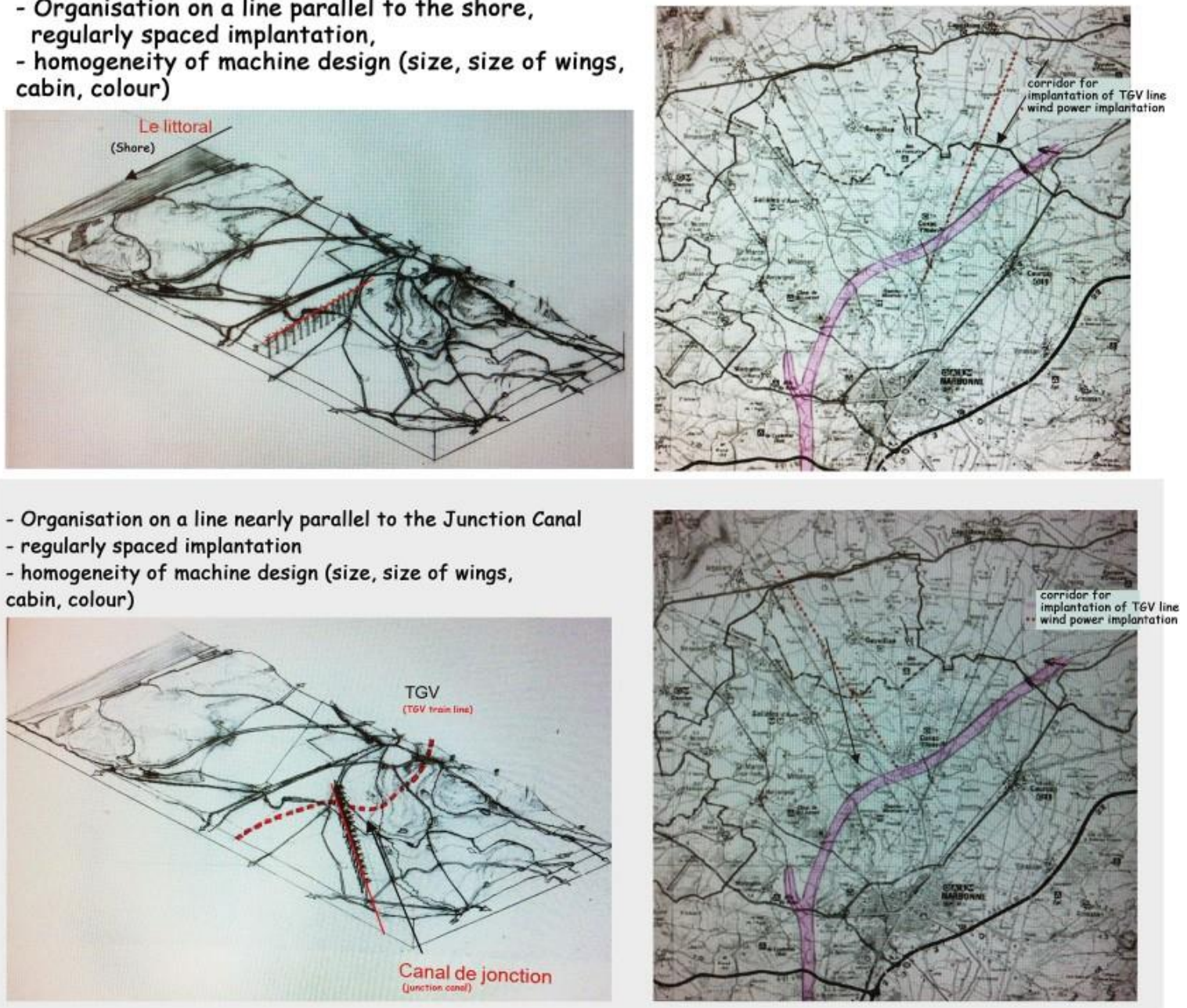

Figure 8. [In colour online.] Propositions 1 and 2 for siting wind turbines in the Aude and Orbieu plain (northern envelope) (source: PNRN, 2003; designed by Agence Urbane and Agence Ectare on behalf 
of the Parc Naturel Regional de la Narbonnaise).

While this planning offers "lines of conduct in terms of project"(40) - that is, in a situation which has reached the stage of siting turbines, it does not interfere with the project itself. For instance the northern envelope, located in the Aude plain, comes with two siting suggestions (figure 8). Both take advantage of elements structuring the landscape (property boundaries, hedges, drainage canals, etc): one is aligned to the shore, whereas the other is aligned to a junction canal (between the canal du Midi and the canal de l'Aude). For both the agency also pictures ways of siting in bunches of five turbines within the same alignments, so that even if recommendations scale up and enter into figurative details exemplification (in the sense of multiplying examples) makes them indicative of an approach rather than prescriptive of a particular mode of siting. It favours relational over spatial reading: "in this way we don't have to say: On this side of the municipal boundary and not on the other, on this slope and not on that ... we avoid too fine a spatialisation." ${ }^{(41)}$

\subsubsection{From plan to situation}

In the end the originality of this planning process lies in the way it frames action for future users of the charter (eg, wind power developers, local actors, etc). The principles included in the charter (the localisation of envelopes and landscape recommendations) are dependent on the scale and situation in accordance with which they have been formulated. The validity of the charter's core principles depends on a type of symbiotic relation between scheme and situation. This situation, the landscape, is endowed with agency, with potentialities "which are there ... germinally [and] dictate very strong ideas [as to] ways of investing a site". ${ }^{(42)}$ So, while principles might well prove inadequate as the process is scaled up towards the project, future users of the charter are always sent back to the situation in which they will have to develop their project. Like the Deleuzian swimming instructor, the planning scheme points to situations endowed with a power of proof: "These are guidelines ... . Fortunately, it is open enough for us to be able to work with the types and the number of turbines that we want. They do not say 'you have to site this turbine here'." They say: "here are the main principles that you have to stick to, then it is up to you to manage your own project." ${ }^{(43)}$ The proof of the pudding is in the eating: the essence of the plan is in the situation. Contingency is at the core of planning.

From November 2003 (when the charter was adopted) to November 2007, developers submitted several wind power projects in the three southernmost envelopes. The contingency of the principles laid down in the charter manifested itself on several occasions. In the envelope of Portel-des-Corbières (ie, the small envelope to the extreme northwest) wind power projects could not be authorised because of the reluctance of the local administration (owing to the presence of the protected site of Fontfroide) and because of a political campaign (opposing the projects) activated by local notables on the national level. In the envelope of Villesèque (ie, the little envelope to the extreme southwest) two projects were rejected and one project was approved. The first rejection was motivated by the use of the envelope as a boundary on the small scale: the project was located outside the envelope. The second rejection was motivated by the fact that the project failed to take into account the situation and the landscape recommendations. The third project, which was approved, testified to the developer's positive interpretation of these recommendations, notably through the adaption of the project to landscape and bird ecology. 
Finally, in the envelope of La Palme, Port-la-Nouvelle, Sigean, and Roquefort (the small easternmost envelope), the use of the charter recommendations enticed the developer to coordinate these municipalities so as to increase the capacity of the park (the first operation of 'repowering' in France), while adjusting the siting of the turbines so as to make them compatible with avian (international) migratory corridors over the site. ${ }^{(44)}$

These developments and the accompanying decisions therefore bore witness to the capacity of the charter to put actors in a position to experience and reinterpret its principles in situ. They show that this 'abductive' dimension helped to enable actors to develop a project approach to wind power landscapes.

\section{The 'map' in the modes that open its forms}

Analysing the Narbonnaise Wind Power Charter as a 'map' points to three ways in which graphic representation is endowed with relational properties: the 'diffraction' of the repre- sentation through a multiplicity of graphic forms; an abductive mode ${ }^{(45)}$ of referencing the space; and specific practices of graphic design (contour blurring, figure/background relationships [scalar dissonance], textual framing, exemplification).

\subsection{A diffracted representation}

Because of its gigantism and its local character (decentralised infrastructure), wind power brings several states and scales of the landscape into relation. The actors engaged in the Narbonnaise planning process (eg, mayors, the PNRN steering committee, the landscape agencies) have adopted multiple perspectives (maps, calques, block diagrams, and texts) in order to render these relations and take advantage of the projective and associative virtues of graphic documents, without ever trapping the planning scheme in a single representation. The analysis shows that what might be called a diffraction of the representational load originates in dialogue and in a constant relay between two modes of representation: representation through the plan (maps, calques) and representation through the situation (block diagrams, texts). Thanks to its graphic design (loose line, floating, or impoverishment of the form), the plan always posits an incomplete order that is relayed by the situation. Conversely, the order thus set allows the situation to be deployed as a principle and to act as a relay without being entirely indexed to its site of origin (absence of a metric scale, exemplification). Plan and situation thus cooperate in mutually reducing their respective representational loads. They conjointly suspend indexing to the territory (topography, regulatory constraints, and administrative and political boundaries) or to a normative scale (within/without the boundary, within/without regulations).

This diffracted way of representing, called by the landscape architect the 'scale' (in singular), works as a sign in the Deleuzian sense (see section 2). Neither the plan nor the blocks fully capture the wind power landscape: the order of the plan (small scale) is incomplete; the situation is never entirely referenced in the blocks (large scale). There is no form in the plan or in the blocks to reproduce; there are only principles of relations to experimental procedures 'through heterogeneity' (in situ). The singularity of landscape situations remains the ultimate testing ground. Planning is a call to return to the field and a resource for doing so. The scale is a sign that circulates and invites the users of the charter to experiment further with a (wind power) relational mode without making the sites into passive substrata for development. 


\subsection{An abductive reference}

The iconographic device-made up of the combination of representation through the plan (maps, calques) and representation through the situation (block diagrams, text)circulates an abductive reference to the emerging wind power landscape.

Interestingly, the circulation of the (wind power) scale can be compared to the (scientific) 'reference' as described by Latour in his (2001) analysis of the work of soil scientists at the edge of Amazonian forests. In this study the ground is gridded, referenced, sampled, and carried off to a laboratory in order to study the desertification of the forest. Latour describes this process of the emergence of the scientific fact as a chain that allows the reference to leave its object (the forest soil) and that allows it to gain in generality by indexing it to shared norms (spatiotemporal coordinates, experimental devices, methodological principles), thus granting the constant possibility of returning to the original fact (the original field) - the well- known traceability of the scientific fact (Latour et al,1986).

Like this reference, the (wind power) scale circulates along a chain of small differences (inclusion of regulatory constraints, contours, impoverishing) through which the definition of the Narbonnaise wind power landscapes gains intensity. As the planning process goes ahead, the potential for wind power development becomes increasingly specified as well as more widely shared. However different from the scientific reference, the Narbonnaise planning process keeps suspending indexing to a shared norm. The scale calls for a constant return to its object as an object that is grasped-in-the-course-of-time. It remains attached to the situation. It appeals to the field by inviting the users of the charter to perform this principle in situ.

In other words the scientific reference affirms the return of the same within a discontinuous mode (it breaks with its origin in time), whereas the scale inscribes the return of the difference within a continuous mode (it maintains its ties with its origin in time). The reference lays claim to stabilising the scientific fact, whereas the scale lays claim to taking account of emergence and novelty. The quality of the chain along which the scale circulates endows its mode of representation with a fundamentally relational and abductive dimension in the sense of a permanent return to (the proof of) its object.

\subsection{A formal practice of abduction}

Abduction, defined on a logical level as a way of inferring a general rule of hypothetical value from a particular case (which means that it is accepted until contradicted), finds here a translation into the practice of iconographic design. Our analysis has detailed the tricks and procedures by which the Narbonnaise planning process has maintained its openness to the multiplicity of situations. The procedures by which graphic forms and planning are kept open are as follows:

The (mere) appearance of the contour. This is crucial in many maps. If loose, a contour can locate a boundary without delineating/drawing it in order to signify an intention (eg, figure 2). If impoverished, schematic, a contour can point to a potential for wind farms without reducing the map to a zoning (eg, figure 7).

The figure/background relationship. A floating relation (as we have called it) between figure and background makes way for a reinterpretation of the form in situ (eg, figure 3) and/or in the perspective of a (previous) experience of the situation (eg, during the consultation). 
Textual framing. In commenting on examples of siting the text points to principles and ways of relating to a situation rather than to metrics of implantation (eg, figure 8). It invites one to experiment with these principles in situ rather than to copy the metrics of the examples. Exemplification. Providing numerous examples of siting in a given situation makes both the examples and the situation indicative of ways of relating (what we have called 'relation principles') rather than prescriptive of a particular implantation (eg, figure 8).

Most of these tricks for opening the graphic forms rely on a common principle which we might call 'scalar dissonance'. ${ }^{(46)}$ Loose drawing, impoverishment of the form, or floating relations between figure and background all rely on a dissonance between the scale of the figure and that of the background which underlies it, making the latter ineffective in indexing the former. The same figure, set on a background with a smaller scale, might enter into scalar consonance with the background and call for a spatial reading.

However, the degree of openness of the map depends not only on graphic forms but also on the context and the social practices in which graphic forms are to be used. Impoverished or loose lines are ways of opening the form that endow it with a relatively high degree of autonomy because the ('poor') form no longer connects to a rich array of indexes and resists lending itself to normative or territorial interpretation. Moreover, the poor form does not call for much framing in order to become abductive (ie, to point to the situation): it is so or else it is useless. Floating forms seem to work in a different way, requiring more framing when they are used. The way in which the agencies floated the inventory maps during the consultation workshops framed participants in circulating from 'tracing' to 'map' - that is, it enabled floating forms to make way for a regime of a-formal circulation (relational).

The importance of social practice is also illustrated by the role played by the PNRN institution, which enabled a collective of local actors to become engaged in planning.

Its political drive to impoverish the graphic form during the third phase of the process, immediately before dissemination, was decisive. This proves, if further proof is needed, that although opening the map relies upon graphic forms it does not entirely depend on them. The relational potential of forms has to be associated with due social practices in order to sustain open planning.

\section{Conclusion}

Semiological analyses of cartography endow the map with the capacity to constitute a semantic and syntactical field (eg, Bertin, 1967; Casti, 2000, page 40). This capacity is seen as a prerequisite: the map has to select and demarcate the real; it has to close itself in order to serve territorialisation. Our attempt proceeds in the reverse fashion: we focus on the ways in which the map is open. We do so, however, without excluding the possibility of a dialogue between the formal and the a-formal regimes. In other words we are interested in the contribution made by the representational field of cartography (for instance, certain graphic codes) to capturing and forming intensities running through its object. Our attempt is motivated by a concrete and contemporary issue: the difficulties that current wind power planning schemes meet in departing from existing landscape codes and forms in order to generate new (wind power) landscapes. Our analysis makes a contribution to three different areas: the typology of wind power planning, collaborative planning approaches, and current theoretical debates on space and landscape. 
The analysis of the Narbonnaise planning process sheds light on the classical distinction between so-called 'constraint' and 'positive' planning approaches, which underlies the ongoing debate about wind power planning (Cowell, 2010; Toke, 2005; Toke et al, 2008). It shows that 'positive planning' is characterised not by the absence of recourse to constraint maps but, rather, by the way in which constraint maps are integrated into the planning process. Beyond this result, the analysis suggests that the frontier between the two types of planning runs along a form of abduction.

Planning theorists have devoted much attention to participative procedures (Forester, 1999; Healey, 1997), in which they see a major factor underlying the possibility of generating new landscapes or new territories. With a few exceptions (eg, Soderström, 2000), they have devoted less attention to the role of graphic forms, which they have often considered to be secondary tools. Analysing the map as an open process made up of graphic forms and of the practices associated with them has enabled us to point to several mechanisms underlying its openness, such as the dialogue between different graphic forms, various graphic procedures for opening the forms, and procedures for framing the interpretation that is to be given to graphic forms (joint texts, ways of using the graphic forms).

Finally, in respect to theories of space and/or landscape, our analysis contributes to the debate on the role and status of representation (see section 1). The approach proposed in this paper, which relies on Deleuzian concepts and is inspired by a materialist approach to the emergence of forms, endows cartographic practice and spatial and landscape representations with a status suitable for theoretical analysis. Under certain conditions, these emergent forms and this emergent practice can contribute to the circulation of a sign, bringing together multiple states of the landscape, favouring shared experience, and enabling experimentation in the search for new landscape options. In our case the sign is a wind power 'scale', which has shown an astonishing capacity to reform the practices of those who use it. By circulating, the scale repeatedly suspends the indexing of graphic forms to preexisting norms and brings forth a progressive referencing to $a$ relational mode that is multiple (dialogue between plan and situation, landscape and site, small scale and large scale) and specific to wind power. In doing so it allows a back-andforth between the formal and the a-formal regimes that, in turn, allows for new associations between things (new landscapes) without fixing them in normative representations.

Acknowledgements. We would like to thank the French Ministry for the Environment (MEDDAD, Program PDD 'Paysage et Développement Durable'), the 'Conseil Français de l'Energie', the French Agency for the Environment and Energy (ADEME) (Convention 0710 C 0019), the Region lle-deFrance, and the Centre National de la Recherche Scientifique (CNRS, Programme Interdisciplinaire pour l'Energie) for their financial support of this research.

\section{References}

Agterbosch S, Meertens Ree M, Vermeulen Walter J V, 2009, "The relative importance of social and institutional conditions in the planning of wind power projects" Renewable and Sustainable Energy Reviews 13 393-405

Aitken M, 2010, "Why we still don't understand the social aspects of wind power: a critique of key assumptions within the literature" Energy Policy 38 1834-1841

Antonioli M, 2003 Géophilosophie de Deleuze et Guattari (L'Harmattan, Paris) Bertin

J, 1967 Sémiologie graphique (Mouton, Gauthier-Villars, La Haye, Paris)

Bonta M, 2005, "Becoming-forest, becoming-local: transformations of a protected area in Honduras" 
Geoforum 36 95-112

Bonta M, 2009, "Taking Deleuze into the field: machinic ethnography for the social sciences" Deleuze Studies 3 135-142

Breukers S, Wolsink M, 2007, "Wind power implementation in changing institutional landscapes: an international comparison" Energy Policy 35 2737-2750

Buydens M, 2005 Sahara: L'esthétique de Gilles Deleuze (Vrin, Paris); originally published in 1990

Casti E, 2000 Reality as Representation: the Semiotics of Cartography and the Generation of Meaning (Bergamo University Press, Edizioni Sestante, Bergamo)

Cosgrove D, Daniels S (Eds), 1988 The Iconography of Landscape: Essays on the Symbolic Representation, Design and Use of Past Environments (Cambridge University Press, Cambridge)

Cowell R, 2010, "Wind power, landscape and strategic, spatial planning-the construction of 'acceptable locations' in Wales" Land Use Policy 27 222-232

Crouch D, Matless D, 1996, "Refiguring geography: parish maps of common ground", in Transactions of the Institute of British Geographers, New Series 21 236-255

De Landa M, 2006 A New Philosophy of Society: Assemblage Theory and Social Complexity (Continuum, London)

Deleuze G, 1994 Difference and Repetition (Athlone Press, London)

Deleuze G, 2005 Différence et répétition (Presses Universitaires de France, Paris); originally published in 1968

Deleuze G, Guattari F, 1980 Capitalisme et schizophrénie Mille plateaux (Éditions de Minuit, Paris)

Deleuze G, Guattari F, 2004 A Thousand Plateaus: Capitalism and Schizophrenia translated by B Massumi (Continuum, London)

Dewsbury J-D, 2000, "Performativity and the event: enacting a philosophy of difference" Environment and Planning D: Society and Space 18 473-496

Doel M, 1993, "Proverbs for paranoids: writing geography on hollowed ground" Transactions of the Institute of British Geographers, New Series 18 377-394

Edney M, 1996, "Theory and history of cartography" Imago Mundi 48 185-191

Ellis G, Barry J, Robinson C, 2007, “Many ways to say 'no', different ways to say 'yes': applying Qmethodology to understand public acceptance of wind farm proposals" Journal of Environmental Planning and Management 50 517-551

Ellis G, Cowell R, Warren C, Strachan P, Szarka J, 2009, “Wind power: is there a 'planning problem'? Expanding wind power: a problem of planning, or of perception?" Planning Theory and Practice 10 521-547

Forester J, 1999 The Deliberative Practitioner: Encouraging Participatory Planning Processes (MIT Press, Cambridge, MA)

Gross C, 2007, "Community perspectives of wind energy in Australia: the application of a justice and community fairness framework to increase social acceptance" Energy Policy 35 2727-2736

Healey P, 1997 Collaborative Planning: Shaping Places in Fragmented Societies (UBC Press, Vancouver)

Herod A, 2011 Scale (Key Ideas in Geography) (Routledge, London)

Hetherington K, Law J, 2000, “Theme issue: After networks" Environment and Planning D: Society and Space 18 127-255

Hoole A, Berkes F, 2010 "Breaking down fences: recoupling social-ecological systems for biodiversity conservation in Namibia" Geoforum 41 304-317

Labussière 0, 2011, “Eléments pour une prospective du milieu. L'enjeu du sensible en aménagement" Cahiers de Géographie du Québec 54 499-515

Labussière O, Nadaï A, 2011, "Expérimentations cartographiques et devenirs paysagers: La planification éolienne de la Narbonnaise" Espace et Sociétés 146 71-92

Latour B, 2001 L'espoir de Pandore: Pour une version réaliste de l'activité scientifique (La Découverte, Paris)

Latour B, Woolgar S, Salk J, 1986 Laboratory Life (Princeton University Press, Princeton, NJ)

Lorimer H, 2005, "Cultural geography: the busyness of being 'more-than-representational'” Progress in Human Geography 29 83-94

Meyer N I, 2007, "Learning from wind energy policy in the EU: lessons from Denmark, Sweden and 
Spain" European Environment 17 347-362

Nadaï A, 2007, "'Planning', 'siting' and the local acceptance of wind power: some lessons from the French case" Energy Policy 35 2715-2726

Nadaï A, Labussière O, 2009, "Wind power planning in France (Aveyron): from state regulation to local experimentation" Land Use Policy 26 744-754

Nadaï A, Labussière O, 2010, "Birds, turbines and the making of wind power landscape in South France (Aude)" Landscape Research 35 209-233

Nadaï A, Van der Horst D, 2010, "Introduction: Landscapes of energies" Landscape Research 35 143-155

Nast H, Pile S (Eds), 1998 Places Through the Body (Routledge, London)

PNRN, 2003, "Charte du Développement Eolien-Projet de Parc Naturel Régional de la Narbonnaise en Méditerranée", Parc Naturel Régional de la Narbonnaise, Narbonne, http://www.parc-naturel-narbonnaise.fr/en_actions/maitrise_de__energie_et_energies_ renouvelables/charte_eolienne

PNRN prefiguration group, 2002, "Narbonnaise Wind Power Development Charter: Proceedings of the meeting of July 11, 2002", Domaine de Montplaisir, Narbonne (in French), available from the PNRN archives

Préfecture de l'Aude, 2005 Plan de gestion des paysages de l'Aude vis-à-vis des projets éoliens Préfecture de l'Aude, Narbonne

Région Languedoc-Roussillon, 2003 Schéma régional éolien 4 volumes, Narbonne

Rey A, 2000 Dictionnaire historique de la langue française Volume 2 (Le Robert, Paris)

Roger A, 1997 Court traité du paysage (Gallimard, Paris)

Rose G, Thrift N, 2000, "Theme issue: spaces of performance, part 1" Environment and Planning D: Society and Space 18 411-517

Rose M, Wylie J, 2006, “Animating landscape" Environment and Planning D: Society and Space 24 475-479

Söderström O, 2000 Des images pour agir: Le visuel en urbanisme (Payot, Lausanne) Thrift

N, 2000, "Afterwords" Environment and Planning D: Society and Space 18 213-255

Toke D, 2005, "Explaining wind power planning outcomes: some findings from a study in England and Wales" Energy Policy 33 1527-1539

Toke D, Breukers S, Wolsink M, 2008, "Wind power deployment outcomes: how can we account for the differences?" Renewable and Sustainable Energy Reviews 12 1129-1147

Van Wezemael J, 2008, "The contribution of assemblage theory and minor politics for democratic network governance" Planning Theory 7 165-185

Warren C R, McFadyen M, 2010, "Does community ownership affect public attitudes to wind energy? A case study from south-west Scotland" Land Use Policy 26 204-213

Wylie J, 2007 Landscape (Routledge, London)

\section{Notes}

(1) See, for example, in the French context Nadaï and Labussière (2009) and in the Welsh context Cowell (2010).

${ }^{(2)} \mathrm{A}$ similar, but not identical, version of this paper has been published in French (see Labussière and Nadaï, 2011).

(3) For a synopsis in the field of landscape see, for example, Wylie (2007).

(4) Hence here 'form' is neither a concept nor an analytical category. We use the term in its very general and common sense-the graphic form, the form of the landscape, etc.

(5) This work revisits the usual operation of diagnostics in territorial development and distinguishes between symptomatology (the study of signs) and aetiology (the identification of causes). Symptomatology finds a theoretical support in the work of Deleuze. It prompts thinking about development to take advantage of aesthetic theories in order to approach geographic milieus as a potential which is apt to orient action towards innovative solutions.

${ }^{(6)}$ This is 'calque' in the French text, a term that we translate as tracing, following Massumi's translation of Deleuze (Deleuze and Guattari, 2004, page 13). 
(7) In France philosophers have put the concept of 'map' in a geographic perspective but they have not derived from it an analytical framework (Antonioli, 2003).

(8) Our reading and use of Deleuze's concepts of 'multiplicity', 'molar' and 'molecular' differ from De Landa's reading and use, which tend to equate 'molecular' and 'molar' with scale ('micro' and 'macro'), and the virtual with a space of possibilities (for a short discussion of this point see De Landa, 2006, pages 125-126, footnotes 6 and 7). Our use is closer to Van Wezemael's reading of these concepts (2008).

(9) For an English translation see Deleuze (1994, page 23).

${ }^{(10)}$ We use the same term used by some interviewees to indicate steps in the development of the Parc Naturel Régional de la Narbonnaise (Regional Natural Park of the Narbonnaise, PNRN) Wind Power Charter. However, our paper is not aimed at discussing the content and definition of this term. For a discussion of the concept of scale see Herod (2011).

(11) For an analysis of the role of the bird protection organisation in this planning process see Nadaï and Labussière (2010).

(12) Interview with the pro-wind nonprofit organisation Ecologie du Carcassonnais, des Corbieres et du Littoral Audois (Ecology of Carcassonais, Corbières and Audois Seashore, ECCLA), 25 January 2005.

${ }^{13)}$ Three interviews were conducted with Agency Urbane (hereafter, the U-agency), Toulouse, two of them with one of the directors responsible for the study contract on the PNRN Wind Power Charter and one with her assistant. For convenience and for stylistic reasons we will sometimes call the Uagency 'the agency' and its director 'the director'. Two interviews were conducted with Agence Ectare (hereafter referred to as the E-agency), Saint Jean, Haute-Garonne, one of whose mission officers collaborated with the U-agency. Interviews will not list individuals but will be referenced as 'interview with the U-agency' or 'interview with the E-agency'.

(14) Interview with the U-agency, 20 November 2006.

(15) Interview with the U-agency, 20 November 2006.

(16) Interview with the U-agency, 12 April 2007.

(17) Interview with the U-agency, 20 November 2006.

${ }^{(18)}$ Interview with the U-agency, 12 April 2007.

(19) Interview with the U-agency, 20 November 2006.

(20) Interview with the U-agency, 20 November 2006.

${ }^{(21)}$ Interview with the U-agency, 12 April 2007.

(22) Interview with the U-agency, 12 April 2007.

(23) Direction Régionale de l'Environment (Regional Environmental Agency).

(24) For an analysis of an example see Nadaï and Labussière (2009).

${ }^{(25)}$ In June 2002 the U-agency was joined by a second landscape company, the E-agency, commissioned to coordinate the second phase of the process and take into account the regulatory zonings.

(26) Interview with the president of the PNRN, 25 January 2005.

(27) Preamble to the questionnaire discussed below.

(28) Interview with the U-agency, 12 April 2007.

(29) Interview with the U-agency, 12 April 2007.

(30) U-agency archives, 2002.

(31) Interview with the E-agency, 3 November 2006.

(32) Interview with the U-agency, 12 April 2007.

(33) Interview with the U-agency, 20 November 2006.

(34) Interview with the E-agency, 3 November 2006.

(35) Interview with the U-agency, 20 November 2006.

(36) Interview with ECCLA, 6 November 2007.

(37) Interview with the U-agency, 12 April 2007. 
(38) Interview with the U-agency, 12 April 2007.

(39) In French "négociation sur le trait".

(40) Interview with the U-agency, 13 December 2006.

${ }^{(41)}$ Interview with the U-agency, 13 December 2006.

${ }^{(42)}$ Interview with the U-agency, 13 December 2006.

(43) Interview with a local wind power developer, 13 April 2007.

(44) For a detailed analysis of the siting process in cooperation with the local bird protection organisation (Ligue de Protection des Oiseaux, Bird Protection League) see Nadaï and Labussière (2010).

(45) On the logical level abduction is a mode of reasoning that consists of the inference of a general rule of hypothetical value from a particular case, which is accepted until contradicted. It is distinguished from from deduction (which submits the explanation to the general rule) and from induction (in which general laws are derived from the observation of a particular case).

(46) In music a dissonance is an 'interval calling for resolution' through an assemblage of sounds (harmony) (Rey, 2000, page 1104). 